\title{
Det omstridda samvetet
}

\author{
Linde Lindkvist \& Johannes Ljungberg
}

Vi lever i en tid då frågor om samvete och samvetsfrihet har blivit alltmer synliga i svensk offentlighet, i såväl rikspolitiken som på tidningarnas ledarsidor och sociala medier. Samtidigt råder det en utbredd oenighet och stundtals påtaglig förvirring om vad som egentligen avses. Samvete och samvetsfrihet är komplexa moraliska, rättsliga och politiska begrepp som inbjuder till olika tolkningar, begrepp som låter sig brukas för skilda syften.

I Sverige och på andra håll i Europa har samvete och samvetsfrihet på senare tid främst kommit att förknippas med vårdsektorn. I vissa sammanhang likställs samvetsfrihet helt och hållet med vårdpersonals rätt att inte behöva utföra vissa arbetsuppgifter med hänvisning till moralisk eller religiös övertygelse. Det finns många olika medicinska ingrepp som kan ge upphov till samvetsbetänkligheter, och vi har troligtvis fler att vänta i takt med en accelererad teknisk och medicinsk utveckling. ${ }^{1}$

Så här långt är det dock särskilt abortfrågan som har hamnat i blickfånget, och då i synnerhet det fall då barnmorskan Ellinor Grimmark inför en rad rättsinstanser och slutligen Europeiska domstolen för de mänskliga rättigheterna yrkade på att samvetsfrihet även innefattar rätten att vägra medverka vid aborter. Det här och liknande fall har sedan 2014 gett upphov till en skyttegravsliknande debatt, där rätten till samvetsfrihet ställts mot kvinnors rätt till säker abortvård och arbetsgivares rätt att specificera sina anställdas arbetsuppgifter. ${ }^{2}$ Fallet gäller modern teknologi, men har samtidigt en påtaglig historisk klangbotten i hur parter i underläge väljer att 
åberopa sitt samvete istället för att visa lydnad mot världsliga eller religiösa auktoriteter i frågor av kombinerat moralisk, politisk och rättslig karaktär.

Samvete och samvetsfrihet dyker upp i fler frågor än abort och vårdvägran. Exempelvis har dessa begrepp också aktualiserats i samband med klimatdebatten och de med denna relaterade uttryck för civil olydnad i form av skol- och arbetsstrejker. När Amnesty International tilldelade organisationen Fridays for Future priset Ambassador of Conscience Award 2018 framställde aktivisten Greta Thunberg klimatrörelsen som en samvetsrörelse: "Att handla efter sitt samvete", inskärpte Thunberg, "betyder för mig att göra det rätta. Att kämpa för vad man tycker är rätt. Att alla har en moralisk skyldighet att göra allt de kan för att förbättra världen."3 Begreppet har också brukats i otaliga kampanjer, debattinlägg och tidningsartiklar om den enskildes ansvar att exempelvis minska sin köttkonsumtion eller dra ner på onödiga flygresor för att "freda" eller "döva sitt klimatsamvete". ${ }^{4}$ I ett större perspektiv kan de industriella åtgärderna i klimatfrågan, i form av handeln med utsläppsrätter och andra konstruerade moraliska marknadssystem för klimatkompensation, närmast framstå som en motsvarighet till 1500-talets avlatsmarknad, där enskilda krämare sålde syndernas förlåtelse som ett substitut för den uteblivna egna moraliska uppryckningen. ${ }^{5}$ Sedan ett antal år tillbaka erbjuds ibland klimatkompensation som ett tillval vid bokning av varor och tjänster, exempelvis flygbiljetter.

Trots dessa olika aktuella exempel kan det ibland verka som att samvete och samvetsfrihet är främmande fåglar i en svensk politisk kultur som sedan folkhemmets dagar har präglats av värden som modernitet, samförstånd, pragmatism och lojalitet med demokratiskt fattade beslut, och detta i stark kontrast till många andra europeiska länder. ${ }^{6}$ Susanne Wigorts Yngvesson har i sin bok Frihet till samvete påvisat hur det i svensk politisk kultur finns en utbredd skepsis mot att tala om samvete, och framhållit detta som en anmärkningsvärd kontrast till den vördnad som visas andra grundläggande fri- och rättigheter. Den här ambivalensen spårar Wigorts Yngvesson framför allt till rättspositivismens starka ställning i svensk rättskultur, men 
också till en generell misstro mot övertygelser som grundar sig i en teologisk världsbild. ${ }^{7}$ I kontrast till bilden av den snåla inställningen till samvete i Sverige har Carola Nordbäck i sin doktorsavhandling Samvetets röst pekat på en förändring under 1700-talet i riktning mot mer generös samvetsfrihet. Nordbäck visar hur fromma rörelser i Sverige under det tidiga 1700-talet började rannsaka sina egna liv strängare och i kraft av dessa självrannsakningar försvara de egna uppfattningarna inför kyrkliga och världsliga myndigheter med explicit hänvisning till samvetets röst. Denna konfliktsituation tolkar hon som ett led i undermineringen av en allmänt rådande korporativ syn på samhällsgemenskapen och en vägröjare för en mer individorienterad människosyn som står i samklang med de moderna friheterna. ${ }^{8}$

De två olika linjer som skisseras hos Wigorts Yngvesson respektive Nordbäck erbjuder båda tankeväckande analytiska aspekter på frågan om samvetets långa linjer i Sverige. Nordbäck sätter ord på en utveckling i riktning mot acceptans för subjektivt uttryckta uppfattningar medan Wigorts Yngvessons iakttagelser påminner oss om att en sådan utveckling varken är rätlinjig eller absolut. När samvetet mobiliseras från makt och myndigheter i vår samtid behöver det inte heller vara den frihetliga dimensionen som står i centrum. När socialminister Lena Hallengren i samband med kungörandet av skärpta restriktioner för att bekämpa coronapandemin i november 2020 uppmanade allmänheten att "göra sitt, inte bara för att lagen

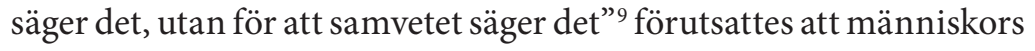
samveten fungerar som en källa till inre disciplin som kan åberopas utifrån för att framkalla lydnad inifrån subjektet självt, och där det rätta handlandet anses ligga i linje med sunt förnuft eller kunna koordineras av experter och offentliga auktoriteter. Exemplet indikerar att antagandet att andras samveten ansluter sig till den egna uppfattningen om de bara hörsammas inte enbart hör till det förflutna. I förlängningen av detta ligger att samvetsfrihetens tillspetsade dilemma i slutändan handlar om tillåtelsen att inte bara få hysa utan också i praktisk handling fullfölja en avvikande uppfattning. På så vis utgör samvetsfrihet en central moralisk och rättslig grund för att legitimera olika former av civil olydnad och icke-konformism. 
Det innebär i praktiken att samvetsfriheten har en central funktion i ett pluralistiskt samhälle, samtidigt som den kan användas för att bestrida demokratiskt fattade beslut. ${ }^{10}$

Att samvetet och samvetsfriheten kan mobiliseras för både lydnad och frihet är kärnpunkten i denna antologi. Det handlar om ett tema som genom historiens gång ständigt har återkommit, intressant nog i nya varianter och sammanhang. Den grundläggande ambitionen med Samvete i Sverige är att undersöka några av de många innebörder som de här begreppen har givits i olika konfliktsammanhang i Sveriges historia och nutid, och därigenom belysa på vilka olika sätt de har använts - både som medel för disciplinering och motstånd; ibland som verktyg för att påverka människors moraliska och religiösa uppfattningar och handlande i riktning mot lydnad, och i andra sammanhang tvärtom för att utmana olika former av arbiträr maktutövning och diskriminerande strukturer, för att motivera utrymmen för frihet och protest i tanke och handling. Sammantaget visar de olika bidragen att varje tid har sitt eget samvete; sina egna konflikter om begreppet och sina egna slutsatser om vems anspråk på samvetsfrihet och moraliskt aktörskap som anses legitimt och tillerkänns handlingsutrymme.

Ett första frö till Samvete $i$ Sverige såddes vid ett forskarseminarium vid Historiska institutionen i Lund på försommaren 2015 då Linde Lindkvist, Johannes Ljungberg, Anna Nilsson Hammar och Joachim Östlund presenterade olika ingångar till dessa frågor. Vi redaktörer hade då precis avslutat respektive var i slutfasen av våra avhandlingsprojekt vilka båda rörde frågor om religionsfrihet, samvetsfrihet och tolerans. ${ }^{11} \mathrm{Vi}$ fann att vi, trots att vi ägnade oss åt olika tidsperioder och institutionella sammanhang, hade flera gemensamma beröringspunkter och samtidigt mycket olika forskningslägen och inte minst teorier om kontinuitet och förändring att förhålla oss till.

Efter ett antal år då undervisning och andra forskningsuppgifter kom emellan valde vi under våren 2019 att plocka upp tanken på ett gemensamt projekt. Det har förvisso skrivits en handfull monografier om samvete och samvetsfrihet på svenska. Vid sidan av ovan nämnda verk av Wigorts Yngvesson och Nordbäck kan här nämnas Görel 
Granströms rättshistoriska undersökning av samvetsvägran inom värnpliktsarmén, Mats Aldéns moralfilosofiska studie av samvetskonflikter i 1900-talets Sverige och Kavot Zilléns rättsvetenskapliga arbete om samvetsfrihet i vården. ${ }^{12}$ Dessa verk ger alla en god inblick i olika konflikter kring samvete och samvetsfrihet som varit aktuella under specifika perioder och i anslutning till särskilda vetenskapliga discipliner. De ger viktiga insikter i olika historiska skeenden och rättsliga dokument, däribland 1686 års kyrkolag, 1809 års regeringsform och Europakonventionens inflytande över nutida svensk lagstiftning och rättspraxis. En sammanhållen läsning av dessa monografier indikerar samtidigt att begrepp som samvetsfrihet och religionsfrihet tenderar att byta skepnad beroende på institutionell ram och frågeställning. ${ }^{13}$ Därför har vi saknat en tvärvetenskaplig bok på svenska som kunde fånga upp och diskutera de här begreppens föränderlighet över tid och göra rättvisa åt den komplexitet som de inrymmer.

Bokprojektet tog sin början med en workshop på Enskilda Högskolan Stockholm (tidigare Teologiska Högskolan) dit vi bjöd in fler forskare som sysslade med frågor om samvete och samvetsfrihet, utifrån såväl historiska som samhällsvetenskapliga, filosofiska och rättsvetenskapliga perspektiv. Tanken var att se vad som händer när vi lägger specialiserade historiska fallstudier om samvete och samvetsfrihet jämte analyser om vilken betydelse och funktion de här begreppen har och skulle kunna få i vår egen samtid. På basis av de utkast som behandlades under workshopen formulerade vi tre gemensamma frågeställningar med relevans för såväl den långa tidsperioden som våra olika vetenskapliga discipliner.

Den första frågan gäller vilka funktioner som referenser till samvetet har haft: Hur har samvete och samvetsfrihet åberopats normativt och hur har detta format olika individuella och kollektiva subjekt? Att tala om samvete väcker frågor om makt: den som åberopar sitt samvete gör samtidigt anspråk på frihet i förhållande till kollektivets krav, antingen de kommer till uttryck i positiv rätt, politiska och religiösa påbud eller samhälleliga konventioner. ${ }^{14}$ Den andra frågan tar därför sikte på hur anspråk på samvete och samvetsfrihet har legitimerats. Det handlar dels om vilka mer omfattande föreställningar om fri- och 
rättigheter som använts för att sekundera anspråk på samvetsfrihet, dels om vilken människosyn som sådana anspråk grundat sig på. Den tredje frågan tar utgångspunkt i insikten om att alla de fallstudier som här presenterats har hämtat väsentlig inspiration från debatter och betydelsesammanhang utanför Sveriges gränser. Alla de bidrag som är samlade i denna volym skildrar konflikter där en för svenska sammanhang ny uppfattning av samvete eller samvetsfrihet gör sig gällande och utmanar etablerade moraliska och rättsliga uppfattningar. Frågan lyder därför: Hur har normbildning utanför Sverige och rörelser mellan olika politiska, kulturella och rättsliga sammanhang påverkat hur frågor om samvete och samvetsfrihet uppstått och behandlats i Sverige?

Samvete i Sverige är resultatet av våra bearbetningar av dessa frågor. I kraft av att arbeta utifrån gemensamma problemställningar utgör de olika bidragen till denna bok, trots avstånd i tid och vetenskaplig disciplin, fallstudier på ett och samma tema. Därtill förhåller sig de olika antologibidragen till ett otal internationella forskningslägen beträffande studiet av samvete och samvetsfrihet. De erbjuder referenser till centrala forskningsdiskussioner inom filosofi, historia, rättsvetenskap, teologi, och i viss mån även biologi och neurovetenskap, för den som önskar utforska frågorna vidare. ${ }^{15}$ Många av bidragen skildrar i grund och botten konflikt- och debattsammanhang där samvete och samvetsfrihet fått representera en specifik ståndpunkt. Som exempelvis Linnea Jensdotter och Susanne Wigorts Yngvesson visar i sina kapitel har den nutida svenska debatten ibland formulerats i termer av för eller emot samvetsfrihet, när det i själva verket handlar om specifika sakfrågor - såsom värnpliktsvägran eller vårdvägran som innehåller flera olika moraliska, rättsliga och praktiska aspekter. I ljuset av detta hoppas vi att de bitvis stora avstånden mellan bidragen i tid och ämne kan ge upphov till nya perspektiv och utmana hävdvunna föreställningar om vad anspråk på samvetsfrihet och på att följa sitt samvete är och kan vara.

I det följande presenteras bokens alla bidrag. Därefter följer en redovisning av några av de viktigaste slutsatserna för boken som helhet. 


\section{Översikt}

Den första och mest omfattande delen av Samvete $i$ Sverige utgörs av bidrag som belyser historiska skeenden och där författarna utgår från historievetenskapliga metoder.

Biörn Tjällén tar ett nytt grepp om den svenska medeltidens enda kända kätteriprocess, mot Botulf i Gottröra socken som förnekade att brödet och vinet förvandlades till Kristi kropp och blod i samband med mässan. Tidigare forskning har primärt intresserat sig för varifrån han fick dessa kätterska idéer, och bjudit på exkurser i olika kätterska uppfattningar om nattvarden som cirkulerade under medeltiden. Tjällén prövar istället teorin att Botulf hämtade sina uppfattningar från kyrkans egen lära om samvetet, vilken förkunnade att samvetet, när det uppfattades rätt, är både bindande och suveränt i förhållande till såväl kyrkliga som världsliga auktoriteter. Botulfs fall skulle därmed utgöra det första bevarade exemplet i Sverige på en gångbar paradox inom den västkristna idétraditionen: uppmaningen till den enskilde att följa sitt samvete, men samtidigt beredvilligheten att utdöma eller sanktionera stränga straff för kätterier. Med denna utgångspunkt följer Tjällén hur samvetsfrågor kommenterades i medeltida biktlitteratur som skulle vägleda präster att ge råd till människor i samband med botens sakrament, vilket även det kallades för "samvetets forum" (forum concientiae). Fjärde laterankonciliet 1215 stipulerade att varje kristen årligen skulle genomgå bikt, vilket uppmuntrade den enskilde till introspektion och moralisk medvetenhet. Samtidigt, vilket Tjällén belyser utförligt, väcktes under denna tid omfattande diskussioner om hur samvetets röst kunde urskiljas, och där prästens position som auktoritativ följeslagare betonades. Resultatet blev att enskilda tvivlande människor, som Botulf i Gottröra socken, på samma gång fick redskap att uttrycka sina dubier och en auktoritativ institution för att granska dem.

Anna Nilsson Hammars bidrag för oss in i det efterreformatoriska Sverige. Den lutherska reformationen hade vid det laget påverkat de institutionella ramarna för samvetskonflikter genom att avskaffa 
bikten, men samvetsfrågor pockade fortsatt på uppmärksamhet. Under 1600-talet ställdes samvetet på ett särskilt sätt i centrum genom inrättandet av en samvetsteologisk disciplin (kasuistik) vid de lutherska universiteten och ökad produktion av litteratur med pastoral vägledning för att möta människor med samvetskval. Med utgångspunkt i kyrkoherden Erik Mattssons skrift Samvetz Plåster från 1638, ett kompilat av texter från lutherska lärde och trösteord från en bredare västkyrklig tradition, ger Nilsson Hammar en inblick i hur frågorna behandlades i svenska domkapitel och av stiftens präster under detta sekel. Att detta egentligen var en genre förknippad med katolska praktiker framgår av förordet, där Mattsson upplever sig behöva försvara att temat är viktigt i ett lutherskt sammanhang. Det hette att samvetet skulle befrias från de bojor som påvens anhängare ville lamslå det med. Bikten tolkades i detta avseende som ett förvridet sätt att låta de små synderna generera ångest. I den lutherska traditionen reserverades därför ordet "samvetssaker" till vad som betraktades som svåra synder, vilket i praktiken sammanföll med de brott som i den världsliga domstolen var belagda med dödsstraff. Likväl, framhöll Mattsson, behövde frågorna om de små synderna behandlas, just för att motarbeta att de annars riskerade att hanteras på ett katolskt vis. Ett övergripande drag vid denna tid som Nilsson Hammars text belyser är hur samvetet hade konfessionaliserats, gjorts till ett lutherskt tillhygge mot en katolsk motbild, samtidigt som vi kan skönja vardagliga betydelser och funktioner av att hantera frågorna.

Johannes Ljungbergs bidrag tar ett nytt grepp om samvetsdebatter i det tidiga 1700-talets Sverige. Under de sex första riksdagarna efter det karolinska enväldets fall, 1720-1739, diskuterades två olika frågor som fick stor betydelse för nya normbildningar i Sverige i fråga om samvete och samvetsfrihet. Den ena frågan handlade om huruvida holländska manufakturister av reformert tro skulle beviljas samvetsfrihet. Den andra frågan kretsade kring pietister, lutheraner som hade börjat samlas i privata hus utan ledning av präst. Saken gällde dels i vilken mån det kunde legitimeras att ställa dem till svars, dels om deras verksamhet kunde försvaras med hänvisning till samvetet. Ljungberg visar att samvetet framstod som ett mycket respekterat 
begrepp som alla parter hänvisade till, och att saken därmed inte gällde principen om det var legitimt att hänvisa till samvetet utan på vilket sätt detta gjordes. Vidare belyser bidraget hur såväl medeltidens som reformationstidens samvetsbegrepp mobiliserades i olika betydelser, jämte en för tiden ny betydelse i form av samvetsfrihet som politiskt verktyg. I anslutning till detta indikerar Ljungbergs bidrag, när det gäller begreppens utveckling över tid, att det tidiga 1700-talet utgjorde ett centralt skede för sammanflätningen mellan samvetsfrihet och religionsfrihet i Sverige. Frågan om den kollektiva samvetsfriheten för de reformerta manufakturisterna kom nämligen att behandlas parallellt med anspråken på samvetsfrihet från enskilda pietister som gick sina egna vägar, i varierande utsträckning som protest mot kyrkoledningen eller i trots mot statsmakten.

I 1700-talets alltmer globaliserade värld växte nya reflektioner om samvete fram. I Joachim Östlunds bidrag får vi följa Georg Sillén, som tillhörde en växande skara svenska ämbetsmän som placerades i tjänst utanför landets gränser, och hur samvete blev ett ledord för honom i internationella relationer. Sillén fungerade som ombud mellan Sverige och Osmanska riket, och befann sig omväxlande i Stockholm och i Konstantinopel. Östlund fokuserar särskilt på Silléns dissertation vid Lunds universitet, Om fördrag med otrogna och barbarer (1744), som med utgångspunkt i västkristen samvetslära argumenterade för att även nordafrikaner och osmaner var utrustade med ett samvete och att det därför var fullt möjligt att sluta fördrag med dem. Silléns erfarenheter och framlagda teser ger oss ett fönster in i en värld där diplomatiska förbindelser utanför den västkristna världen föder fram universalistiska reflektioner om mänskligheten i explicit förbindelse med begreppet samvete. Genom att samvetet artikulerades i dessa diplomatiska förbindelser och infogades i en folkrättslig tradition öppnades också för en form av sekularisering av begreppet. Östlunds text påminner emellertid om att samvetet för den sakens skull inte förlorade sin konfessionella betydelse. Tvärtom framhöll Sillén specifika katolska stater som kraftiga hot mot både protestantiska minoriteter och fördrag med icke-kristna. Samtidigt försvarade Sillén genom sin argumentation för folkrättsliga avtal 
med icke-kristna Sveriges politiska handlande, både i form av Karl XII:s allians med Osmanska riket mot Ryssland under stora nordiska kriget och 1729 års handelsfördrag med Alger.

Att kritiken mot andra statsmakters hantering av protestantiska minoriteter inte utan vidare kan betraktas som en principiell ståndpunkt visar Göran Gunners bidrag om anspråk på samvetsfrihet bland religiösa dissidenter i Sverige under 1800-talet. När baptister och metodister anlände till Sverige under första hälften av 180o-talet kom de till ett Sverige som ännu inte medgav några större friheter på religionens område. Gunner visar hur samvetsbegreppet blev vitalt i deras kamp för religionsfrihet. Centralt för argumentationen var det västkristna antagandet att samvetets frihet mycket väl kan leda till olydnad gentemot kyrkliga och världsliga auktoriteter. Men här bedrevs också en historiskt situerad kamp för att ändra lagstiftningen med hänvisning till samvetsfrihet. Noterbart är hur allianser slöts mellan olika religiösa grupperingar, däribland även judar och katoliker, i enad front mot staten och den lutherska statskyrkan. Bidraget illustrerar därmed hur frågan om samvete, utan att ha förlorat sin teologiska sprängkraft, fick en starkare politisk funktion. I någon mening kan samvetet därmed sägas ha fått en sekulariserad betydelse, även om det var just på religionens område som dessa konflikter utspelade sig.

Görel Granströms bidrag om samvetsvägran inom militären tar sin början i samband med att möjligheten att köpa sig fri från värnplikt avskaffades 1873 och det första organiserade motståndet med hänvisning till samvetet uppstod. Motståndsmännen bestod av en grupp baptister på Gotland. I likhet med de aktörer som framträder i Gunners bidrag var vapenvägrarna i allmänhet tillhöriga frikyrkosamfund. Granström ger en ingående analys av hur frågan bearbetades av riksdagen och statliga utredningar under åren kring den allmänna värnpliktens införande 1901 (då också indelningsverket avskaffades). Intressant nog belyses hur de frikyrkliga inte var de enda vapenvägrarna, men att 1898 års värnpliktskommitté förespråkade att vapenvägran med hänvisning till samvetsbetänkligheter skulle knytas till den frireligiösa grupp som dittills hade rest anspråket. En anledning 
till detta var att de framväxande fredsrörelserna, vilka fanns i både liberala och socialistiska varianter, riskerade att göra anspråk på samvetsvägran. En annan anledning var den principiella hållningen att deltagandet i rikets försvar var en skyldighet som inte kunde vägas mot samvetsfrihet som en personlig rättighet. Som Granström skriver var diskursen om individuella rättigheter svag i Sverige vid den här tiden: "rättigheter kunde möjligtvis erhållas om skyldigheterna hade uppfyllts". Istället låg fokus på att formulera alternativa plikter i form av vapenfria - men helst fortfarande uniformerade - sysselsättningar. Dessa skulle gärna vara svårare eller mer tidskrävande, för att minska attraktiviteten. Anspråken på samvetsfrihet och det organiserade motståndet fick alltså gehör, åtminstone i somliga fall, även om samvetsfrihet inte erkändes som en rättighet.

Den första delen avslutas med Linde Lindkvists bidrag om samvetsfrihet som en mänsklig rättighet. Lindkvist utgår från ett föredrag om de mänskliga rättigheternas historia som Lundaprofessorn och sedermera universitetskanslern Carl-Gustaf Andrén höll 1975, en tid då talet om mänskliga rättigheter precis fått brett genomslag, främst internationellt, men även till viss del i ett svenskt sammanhang. Lindkvist använder Andréns föredrag på två sätt: dels som ett titthål mot det internationella arbetet med att formulera ett folkrättsligt ramverk för mänskliga rättigheter efter 1945, ett arbete där föreställningar om samvete och samvetsfrihet hade stor betydelse; dels som en inblick i en numera bortglömd svensk debatt om mänskliga rättigheter under 1970-talet, en debatt som i huvudsak rörde frågan om konfessionella friskolor. Lindkvist visar hur Andrén grep in i den här debatten genom att hävda att det folkrättsliga skyddet för föräldrars religionsoch samvetsfrihet hade sitt ursprung i en naturrättslig reaktion på de totalitära staternas kränkningar av mänskliga rättigheter under andra världskriget. I kapitlet synliggörs en brytpunkt där den svenska debatten kom att kretsa kring förhållandet mellan svensk rätt och internationella normer på området mänskliga rättigheter. Det är sålunda ett exempel på hur debatter som rör samvets- och religionsfrihet ofta utspelas med en rad externa referenspunkter, antingen i form av motstridiga trender i andra länder, eller, som i det här fallet, 
i form av ett folkrättsligt ramverk som drar i en annan riktning än den svenska rätten.

Spänningen mellan internationell och svensk rätt återkommer också i bokens andra del som består av fyra mer nutidsorienterande och framåtblickande bidrag. Kavot Zillén inleder den här delen med en klargörande rättsvetenskaplig tolkning av rätten till samvetsfrihet, så som den regleras i svensk rätt och i europeisk människorättslagstiftning. Med utgångspunkt i aktuella rättsfall, både i Sverige och i Europeiska domstolen för de mänskliga rättigheterna, ställer hon sig frågan om vilket rättsligt utrymme som vårdpersonal har att agera i enlighet med sina samvetsövertygelser. Hon visar att den som med hänvisning till sitt samvete vill göra anspråk på att slippa utföra vissa arbetsuppgifter i regel måste gå omvägen via den angränsande rätten till religionsfrihet, detta då det i Europakonventionen (som sedan 1995 är inlemmad i svensk rätt) saknas ett uttryckligt skydd för rätten att "utöva sin samvetsgrundade övertygelse". Zilléns kapitel landar i en analys av samvetsklausuler och i ett konstaterande att sådana ofta står i strid med andra viktiga intressen, såsom att trygga en rättssäker och högkvalitativ vård för alla. Hon menar att i den mån som samvetsklausuler överhuvudtaget kan rättfärdigas måste arbetsgivare ges tillräckliga resurser för att inte behöva riskera att underminera andra viktiga samhällsvärden och rättigheter.

Frågan om vårdvägran behandlas också i Linnea Jensdotters kapitel, men nu från en religionssociologisk utgångspunkt. Jensdotter fokuserar på hur debatten om samvetsklausuler i vården till stor del kommit att påverkas av dess mediala inramning. Hennes specifika fall är ett telefonväkteri som P1-programmet "Människor och tro" arrangerade i december 2014, med anledning av de uppmärksammade fallen med barnmorskor som gjorde anspråk på att slippa utföra abortvård med hänvisning till rätten till samvetsfrihet. Lyssnare inbjöds att delta i programmet, antingen genom att ringa in till redaktionen eller genom att göra inlägg på sociala medier med hashtaggen \#samvetsfrihet. Jensdotter visar hur den hybrida mediemiljön bidrog starkt till att skapa en polariserad debatt där samvetsfrihet tydligt kom att associeras med religiöst grundat abortmotstånd och där nyanserna 
i olika argument ofta suddades ut. I medialiserade konflikter, skriver Jensdotter, finns det i regel "ett begränsat antal möjliga positioner att inta”, positioner som redan på förhand definierats som oförenliga.

Även Susanne Wigorts Yngvesson noterar svårigheterna med att tränga förbi den här typen av specifika och känsloladdade dilemman i den samtida debatten om samvete och samvetsfrihet. I en sekulär offentlighet reduceras ofta samvete till övertygelse och samvetsfrihet till konkreta dilemman såsom de ovan nämnda fallen med vårdvägran. Wigorts Yngvesson vänder sig till en rad teologer och filosofer - däribland Hans Ebeling, John Courtney Murray och John Stuart Mill - för att formulera en mer djuplodande förståelse av samvetsbegreppet. Längs vägen noterar hon flera skillnader mellan de traditioner som dessa olika tänkare verkar i, inte minst mellan en katolsk syn på samvetet som grundas i en förståelse av människan med förmåga att följa sitt samvete, och en luthersk tolkning som kretsar kring en medvetenhet om människan som splittrad av synd och samtidigt rättfärdig och som därmed är beroende av Guds medverkan för att följa sitt samvete. Centralt för Wigorts Yngvessons argument är att samvetet föregår konkret tro och specifika övertygelser. Samvetet kallar människan till ansvar, till att svara an mot sin inre röst och det som sker i det omgivande samhället. Samvetet kallar på en fördjupad självreflektion som kan utmynna i, men inte reduceras till, en tro eller övertygelse. Även om samvetet ofta beskrivs som en inre röst eller ett inre ljus framhåller Wigorts Yngvesson att det inte handlar om något organ, utan om en förmåga att vara människa med en medvetenhet om sitt personliga ansvar. Hon avslutar med ett antal reflektioner som återknyter till samvetets och samvetsfrihetens betydelse i en tid som präglas av ett sekulariserat och delvis tillplattat moraliskt språk, samt av ett intensifierat digitalt informationsflöde. Här ställs vi inför frågan om det längre är möjligt att "värna sitt inre rike", om det går att urskilja sin egen röst från tech-företagens signaler som ekar inom oss.

I bokens avslutande kapitel bidrar förläggaren Leif Ericsson med en personlig betraktelse i vilken han försvarar en förståelse av samvete som en allmänmänsklig förmåga till moralisk medvetenhet, men också som en grund för politisk kamp mot olika former av tvång och 
förtryck. Under 1960- och 1970-talen var Ericsson själv en framträdande person i de svenska proteströrelserna mot Vietnamkriget och var med och grundade bokförlaget Ordfront. Hans uttalade kritik mot USA:s krigföring ledde till återkommande konfrontationer med den svenska statsmakten, vilket lade grunden för ett mångårigt intresse för frågor om samvete och samvetsfrihet. I betraktelsen presenterar Ericsson sin tolkning av en av sina inspirationskällor i form av 1600-talsbaptisten Roger Williams, som utvecklade en för sin tid radikal förståelse av rätten till samvetsfrihet vilken han också försökte omsätta till politisk verklighet genom grundandet av kolonin i Rhode Island. Ericsson fokuserar på vad Williams "ropar till vår tid", och illustrerar med sin utläggning hur utsagor om samvetsfrihet som formulerats av religiösa dissidenter under tidigmodern tid kan få förnyad aktualitet och betydelse i vår tid. En central poäng som Ericsson utvecklar med hjälp av Williams och med senare fenomenologiska tänkare är att samvetet "varierar i styrka från mummel och tal till rop" och att den smärta som det framkallar "kan variera från styng, en rysning, till ångest”. Om samvetet ska ta plats i våra liv och samhällen måste vi vara medvetna om de olika sätt som det kommer till uttryck, argumenterar Ericsson. Därför ser han en fara i om samvete och samvetsfrihet i det nutida Sverige nästan uteslutande har kommit att associeras med religion. "Samvetsfriheten har," som Ericsson uttrycker det, "desarmerats genom att den klätts i religiösa termer". Poängen blir att när rätten till samvetsfrihet förvandlas till ett särintresse för specifika grupper finns det också en risk att den rättigheten inte kan fungera på det sätt som den skulle kunna göra, nämligen som ett verktyg för att legitimera "samvetsmotstånd" mot olika former av godtycklig maktutövning och förtryckande strukturer.

\section{Återkommande teman}

Trots att bidragen till Samvete i Sverige utgår från olika perspektiv och täcker olika tider och sammanhang finns det ett antal teman som återkommer. Ett sådant tema, som utgör ett belysande prisma för att skönja kontinuiteter och brott i fråga om människosyn, gäller hur 
samvete och samvetsfrihet förhåller sig till varandra och till andra närliggande moraliska, politiska och rättsliga begrepp. En grundläggande fråga här är om samvete - i den mån det beskriver en verklig, mänsklig förmåga - ger upphov till ett mått av frihet, och vari denna frihet i så fall består.

I medeltidens lärda värld hanterades frågan om samvetets frihet genom en tydlig distinktion mellan människans inre och yttre existens i form av begreppen forum internum, som var samvetets forum, och forum externum, som motsvarade juridikens hägn. Som Zilléns och Wigorts Yngvessons bidrag visar är denna terminologi intressant nog fortfarande i bruk inom vår tids rättsvetenskap respektive etik. Syftet med denna uppdelning var ursprungligen att definiera en distinkt rågång mellan det inre själsliv som enligt den västkristna läran om samvetets helgd absolut inte fick utsättas för tvång och som endast Gud kunde döma, och det yttre handlandet som även det skulle styras av samvetet men över vilket lagens bokstav likväl hade makt. Som Tjällén framhåller i sitt bidrag var det utifrån detta synsätt fullt rimligt att en människa som bröt mot lagen genom att handla enligt sitt samvete må ha handlat riktigt, men ändå rätteligen fick ta sitt (världsliga) straff för sin gentemot lagen olydiga handling. Rättvisa skipades slutligen av Gud efter jordelivet, i det domslut som enligt kyrkans lära gällde evigheten. Även om den enskilde uppmuntrades att följa sitt samvete beviljades alltså inte något utökat socialt handlingsutrymme eller ens någon lättnad i straffpåföljd för den som gick emot lagen. Om rättsstatens sekularisering har upphävt denna logik har den knappast förmått lösa det synbarligen tidlösa dilemmat om samvetsfrihetens förhållande till lagtexten. I den internationella debatten om mänskliga rättigheter under tiden efter andra världskriget, i samband med att FN:s deklaration och Europakonventionen formulerades, inskärptes att samvetsfrihet inte kan fungera som ett carte blanche att fritt få agera utifrån sin moraliska ståndpunkt. Snarare definierades samvetsfrihet ofta i linje med vad Isaiah Berlin har karaktäriserat som en "positiv frihet", det vill säga ett tillstånd som människan uppnår genom att förverkliga sina inneboende förmågor. Inte minst avspeglas detta i talet om att samvetsfrihet är något som 
människan kan träna på, något som människan kan utöva, snarare än ett socialt, politiskt eller rättsligt utrymme för handlande. ${ }^{16}$

Därför är såväl begreppsliga som politiska konflikter om samvete och samvetsfrihet svåra att särskilja från mer grundläggande diskussioner om vad det innebär att vara ett moraliskt subjekt. Här kan det vara lockande att placera in bokens bidrag i en linjär berättelse som rör sig från medeltidens lydnad till nutidens frihet. Ju närmare vår egen tid vi kommer, desto oftare förefaller samvete vara likställt med individuella och subjektiva övertygelser och moraluppfattningar. Samtidigt visar flera av bidragen på begränsningarna med den typen av historieskrivning. Som Tjällén visar fanns även i den medeltida samvetsläran en viss acceptans i praktiken för individuella ställningstaganden eftersom subjektet hade att förhålla sig till olika rättsliga och religiösa auktoriteter som företrädde olika moraliska ståndpunkter. Och i det sena 1900-talets diskussioner om mänskliga rättigheter användes samvetsbegreppet ofta för att ringa in såväl existentiella som samhälleliga risker med en alltför utpräglad moralisk individualism. Föreställningen om ett individuellt samvete har använts som ett redskap för att definiera vad det innebär att vara människa i ett modernt och pluralistiskt samhälle, och samtidigt fungerat som ett medel för att formulera föreställningar om det moderna subjektets tillkortakommanden vad gäller självständigt tänkande och moraliskt ansvarstagande.

Ett begreppspar som återkommer i flera av bokens kapitel är samvetsfrihet och religionsfrihet. Flera av bidragen framhåller hur de här begreppen, åtminstone från 180o-talet och framåt, använts mer eller mindre synonymt, och då främst i syfte att skapa en plats för religiösa dissidenter i det svenska samhället. I modern människorättslagstiftning har de här begreppen också flätats samman på så sätt att de - tillsammans med rätten till tankefrihet - dyker upp i samma konventionsartiklar, vilket inte sällan leder till att begrepp som religion, övertygelse, tanke och samvete likställs med varandra. Flera av bidragen betonar riskerna med en juridisk-teknisk diskurs där nyanserna i de här begreppen försvinner, och både Wigorts Yngvesson 
och Ericsson argumenterar för att samvetsfriheten ska ses som mer grundläggande, och i viss mån mer omfattande, än religionsfriheten.

Här kan det vara klargörande att framhålla att samvetsfrihet före 1800-talet hade en mer avgränsad betydelse i relation till andra frihetsbegrepp. Samvetsfrihet, eller frånvaro av samvetstvång, betecknade specifikt det inre rikets helgd. I lagstiftning omnämndes det för första gången i det franska Nantesediktet 1598, vilket uttryckligen beviljade rikets protestantiska minoritet samvetsfrihet (liberté de conscience). I samma lagstiftning stipulerades en annan frihet i form av ett antal specifika platser för tillåten religionsutövning ( så kallade lieux de culte).${ }^{17}$ I andra sammanhang användes andra begrepp för att auktorisera religionsutövning på olika specifika platser: i hushållet, i en för ändamålet avsedd lokal eller i offentlighetens ljus. Rätten att utöva avvikande religion i hushållet kodifierades för områden tillhöriga Tysk-romerska riket i samband med westfaliska freden 1648 under beteckningen devotio privata (privat religionsutövning). Denna rättighet syftade till att upprätthålla samexistens inom det tyska språkområdets konfessionella lapptäcke av lutherska, reformerta och katolska gemenskaper. ${ }^{18}$ Minoritetskyrkor tilläts bara undantagsvis, ofta på innergårdar eller i privata bostadshus och utan synlig fasad mot gatan så att de inte skulle utgöra ett inslag i gatubilden. ${ }^{19}$ Sammantaget fungerade samvetsfrihet, frihet att utöva religion i hemmet och frihet att utöva religion på anvisad plats i staden som separata regleringar i det tidigmoderna samhället. ${ }^{20}$

1809 års regeringform framstår för svenska förhållanden som en vattendelare mellan att särskilja dessa olika frihetsbegrepp och att tolka dem som olika aspekter av en och samma frihet. Det var formuleringarna i denna lag som de religiösa dissenterna i Gunners bidrag och vapenvägrarna i Granströms bidrag hänvisade till. Lagens bokstav gjorde förvisso uttryckligen skillnad på samvetstvång, hemfrid och offentlig religionsutövning, men de räknades upp i samma paragraf och som Gunners bidrag visar gjorde varken 1800-talets liberaler eller religiösa dissidenter skillnad på dessa kategorier i sin sammanhållna argumentation för både samvets- och religionsfrihet. Detta sätt att uttrycka sig manifesterar emellertid inte bara en 
sammanfogning av olika friheter, utan rimmar väl med tendensen i tiden att talet om generella friheter ersatte forna tiders mer specifika friheter till avgränsade, i bokstavlig mening privilegierade gemenskaper (försedda med privilegiebrev). ${ }^{21}$ Kanske är det mot bakgrund av utraderade gränslinjer mellan dessa mer specifika friheter för samvetet, privata hus och offentliga platser som vi kan förstå varför Sveriges lagstiftare helt utan motivering bytte ut samvetsfrihet mot religionsfrihet i regeringsformen 1976. Bytet blev uppmärksammat, och föremål för rättsliga överläggningar, när samvetsfrihet senare återkom i lagstiftningen då Europakonventionen inkorporerades i svensk lag i samband med EU-inträdet $1995 .{ }^{22}$ Skiftet gav ammunition till offentliga debatter som rörde sig i gränslandet mellan samvetsfrihet och religionsfrihet. I de återkommande offentliga debatterna om skolavslutningar i kyrkan och religiösa friskolor anförs skrivningarna i Europakonventionens dokument om föräldrars samvetsfrihet och rätt att styra över sina barns utbildning i linje med sina egna övertygelser, något som saknas i nationell lagstiftning. ${ }^{23}$

Denna bok är geografiskt avgränsad till att behandla det omtvistade samvetet i Sverige. Det medför inte något anspråk från vår sida om att dessa olika konflikter skulle vara unika för just Sverige. Varje kapitel hade kunnat belysas utifrån komparationer, särskilt med de nordeuropeiska länder som delar både det västkristna och det lutherska arvet, samt den geografiska belägenheten. Istället för att införa systematiska komparationer har vi valt att vara analytiskt uppmärksamma på hur impulser utifrån har tillfört nya dimensioner och gett upphov till nya konflikter kring samvete och samvetsfrihet i Sverige. Det handlar dels, som i fallet med Europakonventionen, om hur normbildning utanför Sverige har påverkat svensk lagstiftning och bidragit till att föra in nya aspekter i debatter som rört anspråk på samvetsfrihet, dels om hur fysiska möten i och utanför Sverige har gett upphov till nya frågeställningar och dynamiker. De medeltida bikthandledningar som Tjällén analyserar införde en del av det västkristna tankegods som var utformat utanför Sveriges gränser, oberoende av svenska förhållanden, i Sverige. Den samvetslitteratur i 1600-talets Sverige som Nilsson Hammar tar upp till diskussion var 
importerad från det tysktalande lutherska närområdet, och författad i polemik mot vad som i de reformatoriska konflikterna uppfattades som katolska missbruk. Östlund speglar hur intensifierade möten utanför Sveriges gränser gav direkt input till den svenska universitetsvärlden och ämbetsmannakåren, medan Ljungberg och Gunner belyser hur uppkomsten av nya religiösa dissenter och minoriteter under 1700- respektive 1800-talen gav upphov till en ny dynamik för frågor om samvetsfrihet. I 1900-talsbidragen spelar internationell idéutveckling och konventioner, och deras förhållanden till svensk lagstiftning, en särskild roll. Samvetsbetänkligheter kring värnplikt och dilemman inom vården tog form samtidigt $\mathrm{i}$ olika delar av världen, och som Zilléns bidrag visar har protester, debatter och lagstiftningar i exempelvis USA påverkat hur abortfrågan debatteras i Sverige. Vidare har det svenska barnmorskemålet från början inspirerats av en annorlunda norsk lagstiftning, uppmärksammats i andra stater och avgjorts i Europadomstolen. Som Wigorts Yngvesson och Jensdotter framhåller i sina bidrag påverkas även samvetsfrågornas form och innehåll av förändrade medielandskap och utveckling av ny teknik som inte är specifik för Sverige. Sammantaget omvittnar dessa olika exempel på nya betydelser genom nya impulser en flexibilitet hos begreppen samvete och samvetsfrihet. Det ger anledning att förvänta sig att anspråk på samvete och samvetsbegrepp kommer att återkomma på nya sätt.

\section{Uppslag till vidare forskning}

Som alltid när man sätter samman en antologi av det här slaget är det en utmaning att föra samman bidrag som är skrivna inom olika vetenskapliga fält och som förhåller sig till olika forskningsfronter. Dessutom grunnar man som redaktör i slutänden alltid på bokprojektets brister, på de texter som vi saknar och som gärna kunde ha tillkommit i det här sammanhanget. En av de mest påtagliga luckorna i denna volym gäller de många frågor om samvete och samvetsfrihet som väcks till följd av det faktum att Sverige under de senaste decennierna blivit ett alltmer pluralistiskt samhälle i fråga om kultur och 
religion. Flera av bidragen berör förvisso erfarenheter av att tillhöra en minoritetsgrupp eller att befinna sig i utanförskap, och därmed slitas mellan de moraliska skyldigheter och seder som springer ur den egna traditionen och det omgivande samhällets mer eller mindre uttalade förväntningar. Men inget av bidragen handlar specifikt om islam, judendom eller ortodox kristendom, och vi saknar också bidrag som är skrivna med särskilt fokus på exempelvis funktionsvariation eller sexuell identitet.

På samma sätt finns det en rad historiska och samtida samvetsfrågor som inte ges någon utförlig behandling i den här boken. Däribland ingår olika typer av visselblåsare när det gäller digital säkerhet, djurrättsaktivister och kvinnoprästmotståndare. Benämningen "samvetsfånge", använd av Amnesty International sedan andra hälften av 1900-talet, och termen "klimatsamvete" är två begrepp som har gett samvetet nya betydelsesammanhang. En del av de här frågorna har utförligt analyserats på annat håll, medan andra borde vara fruktbara ämnen för vidare studier. ${ }^{24}$ Det finns också utrymme för vidare forskning i anslutning till den moderna psykiatrins historia, exempelvis framväxten av begreppet "psykopat" som har använts för att beteckna en person som anses sakna samvete.

Vår förhoppning med Samvete i Sverige är inte i första hand att vinna läsarens bifall. Istället hoppas vi att boken ska kunna ge såväl teoretisk inspiration som konkreta uppslag till fördjupade studier i samvetets och samvetsfrihetens olika betydelser. Vi hoppas också att den kan ge inspiration till liknande tvärvetenskapliga projekt som tar sikte på att öka förståelsen av hur olika moraliska, politiska och rättsliga begrepp har använts över tid. Vi tror att den typen av undersökningar inte enbart är av antikvariskt värde, utan kan ge nytt liv åt vårt moraliska, politiska och rättsliga tänkande. ${ }^{25} \mathrm{I}$ bästa fall kan sådana studier hjälpa oss att reflektera över vilka roller som samvete och samvetsfrihet kan fylla i våra hyperteknologiserade och påtagligt globaliserade samhällen, samhällen där uråldriga begrepp som samvete och samvetsfrihet fortfarande har en märkbar attraktionskraft. 


\section{Noter}

$1 \quad$ Se Kavot Zilléns bidrag.

2 Se Linnea Jensdotters bidrag.

3 Sveriges Radio, "Stort Amnesty-pris till Greta Thunberg", 7 juni 2019, https://sveriges radio.se/artikel/7237430 (hämtad 14 september 2021).

4 Set. ex. Anders Friström, "Klimatsamvete med förhinder," Sveriges Natur, nr 5 (2007). https://www.sverigesnatur.org/arkiv/klimatsamvete-med-forhinder/ (hämtad 13 september 2021).

5 För en uppdaterad skildring av denna konflikt, se Andrew Pettegree, Brand Luther: 1517, Printing, and the Making of the Reformation, New York: Penguin Press, 2015, s. 53-83. Angående relationen mellan avlatslära och avlatshandel samt missförstånd om bruk och missbruk, se Anders Fröjmark, "Den missförstådda avlaten", Religionsdidaktiska studier, Växjö: Linnaeus University Press, 2015, s. 75-87.

6 Johan Östling, Nazismens sensmoral: Svenska erfarenheter $i$ andra världskrigets efterdyning, Stockholm: Atlantis, 2008, s. 189-193.

7 Susanne Wigorts Yngvesson, Frihet till samvete, Stockholm: Timbro, 2016.

8 Carola Nordbäck, Samvetets röst: Om mötet mellan luthersk ortodoxi och konservativ pietism i 1720-talets Sverige, diss., Umeå universitet, 2004, särskilt s. 397-413.

9 Sveriges Radio, "Löfven: 'En mycket tydlig och skarp signal'", 16 november 2020, https://sverigesradio.se/artikel/7600690 (hämtad 16 november 2020).

10 För mer om förhållandet mellan samvetsfrihet och civil olydnad, se Kimberley Brownlee, Conscience and Conviction: The Case for Civil Disobedience, New York: Oxford University Press, 2012; Jennie Ikuta, Contesting Conformity: Democracy and the Paradox of Political Belonging, New York: Oxford University Press, 2020.

11 Linde Lindkvist, Religious Freedom and the Universal Declaration of Human Rights, New York: Cambridge University Press, 2017; Johannes Ljungberg, Toleransens gränser: Religionspolitiska dilemman i det tidiga 170o-talets Sverige och Europa, diss., Lunds universitet, 2017.

12 Mats Aldén, Samvete och samvetsfrihet: En analys av samvetskonflikter i det svenska samhället och av begreppen samvete och samvetsfrihet, diss., Lunds universitet, 2002; Görel Granström, Värnpliktsvägran: En rättshistorisk studie av samvetsfrihetens gränser i den rättspolitiska debatten 1898-1925, diss., Uppsala universitet, 2002; Kavot Zillén, Hälso- och sjukvårdspersonalens religions- och samvetsfrihet: En rättsvetenskaplig studie om samvetsgrundad vägran och kravet på god vård, diss., Uppsala universitet, 2016. Samvetsfrihet och religionsfrihet har även behandlats i ett par filosofiska och rättsvetenskapliga antologier, se exempelvis Johan Modée och Hugo Strandberg (red.), Frihet och gränser: Filosofiska perspektiv på religionsfrihet och tolerans, Eslöv: Brutus Östlings bokförlag Symposion, 2006; Hedvig Bernitz och Victoria Enkvist, Freedom of Religion: An Ambiguous Right in the Contemporary European Legal Order, Oxford: Hart Publishing, 2020.

13 Se även Victoria Enkvist, Religionsfrihetens rättsliga ramar, Uppsala: Iustus förlag, 2013.

14 Aldén, Samvete och samvetsfrihet, s. 18-23.

15 Den här litteraturen är för omfattande för att sammanfattas här. Istället hänvisas till de enskilda bidragen. För en övergripande introduktion till den moralfilosofiska debatten om samvete och samvetsfrihet, se Paul Strohm, Conscience: A Very Short 
Introduction, New York, Oxford University Press, 2011, samt Edward G. Andrew, Conscience and Its Critics: Protestant Conscience, Enlightenment Reason, and Modern Subjectivity, Toronto: University of Toronto Press, 2001. Frågan om samvete har också på senare år blivit central inom fält som socialpsykologi och neurofilosofi. För två aktuella exempel, se Patricia Churchland, Conscience: The Origins of Moral Intuition, New York: W. W. Norton, 2019 och Steven Hitlin, Moral Selves, Evil Selves: The Social Psychology of Conscience, Basingstoke: Palgrave Macmillan, 2008. Isaiah Berlin, Four Essays on Liberty, Oxford: Oxford University Press, 1969. För en kritisk läsning av Berlins distinktion, se Lena Halldenius, Liberty Revisited: A Historical and Systematic Account of an Egalitarian Conception of Liberty and Legitimacy, diss., Lunds universitet, 2001.

17 Guy Saupin, "Le concept de tolerance aux Temps modernes", i La Tolérance: Colloque international de Natenes, red. Guy Saupin, Rémy Fabre \& Marcel Launay, Presses universitaires de Rennes, 1998, s. 16-17.

18 Klaus Schreiner, "Toleranz", Geschichtliche Grundbegriffe: Historisches Lexikon zur politisch-sozialen Sprache in Deutschland. Bd 6, Stuttgart: Klett-Cotta, 1990, s. 498.

19 Benjamin J. Kaplan, "Fictions of privacy: House Chapels and the Spatial Accomodation of Religious Dissent in Early Modern Europe", The American Historical Review, 107:4 (2002); Benjamin J. Kaplan, Divided by Faith: Religious Conflict and the Practice of Toleration in Early Modern Europe, Cambridge, MA: Belknap, 2007, s. $172-197$.

20 Härvidlag framstår kyrkohistorikern Mette Birkedal Bruuns modell över olika "heuristiska zoner" som arenor för olika gestaltningar av tidigmodernt privatliv som ett givande analytiskt verktyg för att förstå avgränsningar i anspråk på samvetsfrihet i relation till anspråk på andra friheter. Se Mette Birkedal Bruun, "Towards an approach to early modern privacy. The retirement of the great Condé", i Early Modern Privacy: Instances and Approaches, red. Michaël Green, Lars Nørgaard \& Mette Birkedal Bruun, Leiden: Brill, 2021.

21 Horst Günther, Werner Conze, Diethelm Klippel et al., "Freiheit", i Geschichtliche Grundbegriffe. Band 2, Stuttgart: Klett-Cotta, 1978, särskilt s. 450-452, 484-493.

22 Reinhold Fahlbeck, "Religionsfrihet och mänskliga rättigheter", Juridisk tidskrift 15:1 (2014), s. 3-5; Victoria Enkvist, Religionsfrihetens rättsliga ramar, Uppsala: Iustus förlag, 2013, s. 84-122.

23 Hedvig Bernitz, "Rätten att inrätta undervisningsanstalter och föräldrarätten. Rättighetsstadgans artikel 14.3 i Sverige", Svensk juristtidning, nr 8, 2016, s. 583-596. Angående de offentliga debatterna, se t. ex. "Obehaglig attack på religiösa skolor", 30 juni 2016, https://www.svt.se/opinion/markus-uvell-om-friskolor (hämtad 22 mars 2021).

24 Se ex. Tobias Kelly, "A Divided Conscience: The Lost Convictions of Human Rights?", Public Culture 30:3 (2018), s. 367-392; Susanna Mancini och Michel Rosenfeld (red.), The Conscience Wars: Rethinking the Balance between Religion, Identity and Equality, New York: Cambridge University Press, 2018.

25 Se Quentin Skinner, Liberty before Liberalism, New York: Cambridge University Press, 1998, s. 112. 